\title{
Preventing Radicalism Through The Values of Pancasila and Instilling the Value of Character in Young Citizens
}

\author{
Fransiskus Markus Pereto Keraf1,a, and Fredik Lambertus Kollo,b, \\ 1Department of Civic Education, Faculty of Social Science Education, Indonesia University of Education, Bandung, 40162, Indonesia \\ 2Department of Civic Education, Faculty of teacher Training and Education, Nusa Cendana University, Kupang Indonesia \\ a keraffransiskus@gmail.com; bredikkollo@yahoo.co.id \\ ${ }^{*}$ Corresponding Author \\ Whatsapp Number [+628525326837]
}

How to Cite: Keraf, F.,M,P. \& Kollo, F.,L. (2019). Preventing Radicalism Through The Values of Pancasila and Instilling the Value of Character in Young Citizens. International Journal for Educational and Vocational Studies, 1(4), 339-344

\section{ARTICLE HISTORY}

Received: 16 May 2019

Revised: 12 June2019

Accepted: 7 August 2019

\section{KEYWORDS}

Countering Radicalism;

Pancasila;

Character;

Citizen ;

\begin{abstract}
The purpose of this study is to determine the role of teachers in instilling the values of Pancasila and the character of the students (young citizens) in Atambua junior high school. Atambua is one of regencies in East Nusa Tenggara province which borders between the State of Indonesia to Timor Leste. Based on observations of researchers that in Atambua junior high school, Civics teachers play an active role in instilling the values of nationalism character in students. Pancasila as a guide to life in Indonesia so it is important to preserve. Efforts to strengthen the values of Pancasila by civics teachers during the learning process. The object of research in Atambua junior high school. The method used in this research is qualitative descriptive form. The results show that teachers strive to instill nationalism Civics on student Atambua junior high school. The technique used by civics teachers in instilling nationalism is to engage students in the class to play drama. Drama prepared by the teacher and played by students. The play contains the living example with berpadomana on Pacasila values, sense of responsibility, nationalism, and self-confidence as a citizen of Indonesia. After the students play the drums, the teacher asks the students to conclude messages and images in the drama. In addition, one of the efforts that teachers do is to always provide various examples of harmony in the lives of diverse ethnic, religious and cultural.
\end{abstract}

This is an open access article under the CC-BY-SA license.

\section{INTRODUCTION}

Pancasila is a noble heritage of the founders entrusted to the Indonesian nation to maintain its existence. The noble heritage, should serve as guidelines and philosophy of life of Indonesia. Kaelan (2013: 56) argues that the way of life and philosophy it is the crystallization of value - the value to be true by the Indonesian people who pose for him to make it happen in the attitude of behavior and actions. Attitudes and behavior patterns of Indonesian society should reflect the process ofbasic implementation values of Pancasila. Kaderi (2015: 4) argues that Pancasila as a statement of identity of Indonesia, which is the result of the ideas and the basic idea of the Indonesian nation of the good life that give character, style, and characteristic of Indonesian society. Since it started the process of formulation, Pancasila has always claimed to be the crystallization of the noble values of the Indonesian nation, so it is necessary to study more in-depth, about the values and judgments until it reaches a new understanding of the operational level of the value of the Deity, Humanity, Unity, Democracy and Justice (Krishna,
2013), Notonagoro in Sukarno (2017: 23) argues that Pancasila is creativity and new appropriate form to the circumstances than ideology of Indonesia.

Indonesia nowadaysis experiencing mental degradation marked by numerous abnormal events. These events show that Indonesia people no longer make Pancasila as the source of identity and personality. Latif (2011: 41) explain that Pancasila is a source of identity, personality, morality, and the direction of the nation's salvation. The Indonesian state is based on five fundamental principles (Pancasila): belief in one god, humanitarianism, national unity, consensual democracy, and social justice (Weatherbee, 1985). Pancasila is already very holistic. It consists of five principles items, namely: (1) Belief in theone supreme God, (2) Just and civilized humanity, (3) The Unity of Indonesia, (4) Democracy wisely led by the wisdom of deliberations among representatives (5) Social justice for all the people of Indonesia (Ludigdo \& Kamayanti, 2012). 
Research conducted by Murdiono (2014: 353) shows that the values of Pancasila can be used as transcendental anchors for Indonesian citizens, namely the values that serve as a grip and the basis of foothold in daily life. The process of implementation of basic values should be practiced throughout Indonesian society, including in the border region. The border region is the most vulnerable to misappropriation of values. This is certainly justified, since the border regions will actually get much foreign influence in the process of strengthening values. The life of Indonesian people, especially the younger generation in this era of globalization, has a very strong influence from outside cultural values, so that began many attitudes and behaviors that are not in line with the values of Pancasila (Maftuh, 2008). If the absence of reinforcement and also filter against foreign influences is by itself the values on the basis of the guidelines of life in Indonesia will be lost. Therefore certainly needed all the community's role in addressing this phenomenon. Which is considered very vital role in providing a strengthening of the value - the value of Pancasila is the formal educational institutions. In this case the school has a very important role in the process of strengthening the values and character of optimal growth in the development of citizens, especially young citizens.

Education of a nation will automatically follow the ideology nation. Therefore, the national education system should be imbued, based, and reflect the identity of Pancasila (Sutono, 2015). Research conducted by Ludigdo (2013: 13) concluded that Pancasila implanted but with a pattern that emphasizes critical grindstones learners to understand Pancasila with all the potential intelligence, absorb its values with sincerity, implementing it with sincerity, and pass it with confidence.

Character education is one factor in shaping the behavior patterns of citizens. Kawuryan (2010: 101) of character education efforts to develop various aspects, such as knowledge, emotional, and behavioral of life. The formation of character is considered important by various groups, refers to the phenomenon that developed in the community about the issue of radicalism and others. Rubei (2015: 199) social-cultural issues and characters in the life of the nation into the public spotlight in various aspects of life that often appear in the print media or electronic media, in addition to the media also frequently discussed in official forums such as national and international seminars on various issues appears in the community.

The phenomenon that often occurs in the life of the nation that the problem of radicalism that led to a tribal conflict, culture, and religion in society. Pancasila and Civic Education Teacher in Atambua junior high school attempt to counteract the occurrence of radicalism by young citizens in border areas of Indonesia and East Timor (Atambua district) by optimizing the material character of nationalism that aims to make the students become citizens of Pancasila of this study to develop multimedia learning, especially in science learning that can help students and teachers understanding concepts related to science topics.

\section{METHODS}

The method used in this research is descriptive qualitative method. The data analysis technique used qualitative data analysis, which consists of data reduction, data presentation, and conclusion drawing. Data obtained from observations and interviews conducted in school, then summarized and concluded. From the results of the analysis, the things needed in the development of multimedia learning obtained. Part of the interview.

Researchers conducted interviews with the father and mother of the subjects Civics teacher at Atambua junior high school on research problems studied by the researchers. Researchers observe the civics learning activities with role-play method that contains loads of character and attitude of nationalism as Indonesian citizens. In addition, data collection through technical documentation by the research that is trying to collect the data documentation of the learning activities Civics in Atambua junior high school.

\section{RESULTS AND DISCUSSION}

Based on the results of the study revealed that at school the border region, especially in Atambua junior high school, there are efforts made by teachers Pancasila and Civic Education through a learning process for countering radicalism. The method used by one of the teachers in these schools are playing a drama. Teachers make a drama played during the learning process, played by students in the classroom. The drama created by teachers according to subject matter and contains the charge values of Pancasila, nationalism as a citizen of Indonesia, and examples of learners at the same character as a good citizen.

This drama is one activity that is quite effective in the classroom, because it gets high motivation of learners in the classroom. This activity proved with great enthusiasm of the learners in playing their respective roles. In the process of this activity, the teacher as a facilitator in setting up the concept and discourse in the drama. The drama played by the students in this class each - each getting a different task. The tasks that played in the drama is first, learners contribute to the lives of Indonesian citizens as examples which are based on the values of Pancasila. Secondly, the learner role as citizens who uphold nationalism in the border area (border between countries). Third, the role of learners with other learners as examples of character. Fourth, the role of the learner as examples of students who are not in character.

The purpose of the drama created by the teacher is to improve the attitude of nationalism of young citizens (students) in the border areas. Nationalism in border areas should be maintained by the young citizens of the 
country in order to ward off the radicalism that emerged in the border area. Student Atambua junior high school very enthusiastic with the drama and they continue to play with (another school friend) through the story in Pancasila and civic Education in the classroom we were asked to play dramas created by teachers with the content of the drama is to model the lives of citizens who are guided by the values of Pancasila, our life in the border area and as a good schoolchild. From the story told another friend that the friend who got the story of the play, and then they were curious and asked to play the same drama in the afternoon when they exercise in the field. Time to exercise a bit preoccupied because friends were still watching the drama that played short and simple. Friends who watch later say that we as citizens who reside and interact in the border area should reflect the Pancasila in our lives. As a form of application then we must have a loving soul Countries Indonesia's diverse cultures, ethnicities and religions. In other words that we must make the diversity as a unifying tool of the nation not the other way around.

In general, students in Atambua junior high school said that the diversity owned by the Indonesian people should be preserved not be a difference to solve citizens with various conflicts that are oriented to the diversity owned by the Indonesian Nation. In addition, there is also a student who has the same view of the diversity of it. The student said that different is beautiful and differences make us happy, supposing batik clothes that look beautiful and attractive.

In the border areas, the formation of personality became quite urgent in the process of growth of young citizens. The process of growing the values that is one way to prepare young citizens to welcome foreign cultural influences. One way that is considered to have an important role in responding to a foreign culture is to behave in accordance with the values - values of Pancasila. Suryohadiprojo (2014: 175) it is hard to imagine the life of a truly prosperous Indonesian nation without Pancasila which is a formulation of Indonesian cultural attitudes. Values are the result of the excavation of the element values and habits of life in society (Kaelan, 2013). Soemardjan in Alfie (1990:: 171) of the Republic of Indonesia will not be living with a sustainable and prosperous if Pancasila only be soul to the nation and does not seep into the soul of its people. Pancasila provides a distinctive pattern and can not be separated from the Indonesian people so characteristic which distinguishes the Indonesian nation with another nation (Salam, 1988). Pancasila is seen as an ideology which contains three important dimensions in maintaining its relevance to the times. These three dimensions are (1) the dimensions of the reality, (2) the dimensions of idealism, (3) the dimensions of flexibility (Alfian, 1990).

The revitalization process of Pancasila conducted by teachers in the border area is a matter that is considered positive. Channel information through the school or educational institution is certainly shaped the teaching given by the teacher to his student, in this case depends on the intellectual quality of the teacher asking to be absorbed by the student (Alfian, 1990). In the beginning teachers of Pancasila Education and Citizenship must provide understanding to learners about the appreciation and belief in the values contained in Pancasila (Latif, 2011). There is another model that is practiced by the teachers at the border to revitalize Pancasila, namely using stories. The story generated varied by teachers felt able to connect the patterns of behavior in the story with the facts nor the expectation gap desired by learners. The story has always been a teaching instrument preferred by the world's moral teacher because a good story can stir strong feelings so as to develop the emotional side of the character of the learners (Lickona, 2016). It required quite a long time through a process of continuous education and directed so that the awareness and readiness to implement Pancasila can be done in the practice of daily life - the day through education and in fact live in a society (Kaelan, 2013).

In revitalize Pancasila to do is turn on and strengthening the nation's cultural attitudes, but the process was not until the ultimate goal is not integrated on the core values of Pancasila with the intent and purpose (Suryohadiprojo, 2014). Preserving the efficacy and supernatural power of Pancasila needs to be cultivated in a real and continuous manner through appreciation and practice of the values contained therein by every Indonesian society (Salam, 1988). Revitalization of Pancasila to students in schools should be based on the practice of every precept. Kaelan (2002: 185) Pancasila is a value system, therefore the principle of Pancasila is essentially a unity. The process of practicing Pancasila can be done in daily life if the attitude, mental, mindset and behavior have been imbued the Pancasila precepts and not contrary to the existing norms (Darmodiharjo et al, 1991).

Based on the views of above, then the teachers of Pancasila and Citizenship Education in the border region, especially in Atambua junior high school always try to revitalize Pancasila with the aim of creating learners as citizens Pancasila with high nationalism. The formation of nationalism attitude towards young citizens (learners) is necessary in order to be the provision of public life. Nationalism is indispensable for people in border areas which border between the State of Indonesia to Timor Leste. Good nationalism can maintain the integrity and prosperity of a nation and national development will be better (Chen, 2003).

The attitude of nationalism of every citizen becomes important to be developed both in the family environment and school. The formation of nationalism in school through extra school activities and the learning process, particularly on the subjects of Pancasila and citizenship education. Nurdin (2017) through civic education can instill norms of a democratic one's life so that it can soulless justice, responsibility, patriotism and honesty in citizens. Schools must create students who are loyal, 
honest and critical thinking and the development of civic education is key in the process of formation (Leung, 2004).

The values in public life in Atambua of course guided by the values of Pancasila. In addition, people in Atambua also upholds the values of their culture. The values of religion and culture becomes a source of strength in life and at the same time be the glue in society, values such as these must be preserved in the life of nationals (Bekerman \& Zembylas, 2017). Similar feelings were expressed by Hung (2014) nationalism in line with communitarian emphasis on social commitment and cultural order.

The social life of the community in reference to the national identity. National identification referring to the promotion of national identity with cultural and political nature, aspects of community life refers to the national identity (Yuen \& Mok, 2014). Different human behavior oriented relationship between the fellow to be able to guarantee the welfare of citizens (Leung and Yuen, 2012).

Various examples of people's lives by reference to the attitude of nationalism. One example nationalism of the students at SMP Negeri 1 Atambua is to always use domestic products even though they are in the border area. Nationalism can be exemplified in the sports field that refers to the social phenomenon and create a sense of solidarity (Tosa, 2015).

In general, parents want their children to be equipped with a variety of materials so that his character could be a citizen of character. Lickona (2013: 45) need to realize that parents make efforts wholeheartedly in order to meet the needs of children. The family has an important role in shaping the character of each individual (Sulityowati 2012: 13). If people in the house the family community shall assist child development patterns (Koesoema, 2012: 144). Megawangi (2004: 64) The character development is inseparable with shaping the personality of each individual within the family and the school. Schools have a role in shaping the character of students through a learning process in the classroom and extra activities at school. In the social context of each individual emphasis on behavior as well as keeping the universal rights of every person (Gerson \& Rubin, 2015).

Students follow the training done by the teacher, with a new drama model. The teacher always introduces innovations to improve the learning style and quality of students. A look at radicalism is increasingly attracting public attention. Communities in the border area play an important role in ensuring security in the border region, so that the values of nationalism continue to develop. Considering this, in order to train young citizens, it is necessary to instill in the good values of character and nationalism, so that young citizens or pupils become examples and always preserve the integrity of the nation in the border area.

Radicalism becomes a form of crime, which violates the comfort of society. Radicalism, which still causes public concern, should prevent it from remaining among adolescents. Influence for adolescents who are quickly inclined to commit a crime of radicalism, since the teacher must foresee and prevent in school through classroom instruction. The city of Atambua is one of the border cities between countries, so it is necessary to easily prepare citizens in the border zone. One of the efforts of teachers to train young citizens who love or support the values of nationalism is classroom instruction. Each training takes place, the teacher always tries to pack the material well and always assumes nationalist values for the students.

The Indonesian nation is a diverse nation that has the characteristics of a diverse society, or in this case, a diversity that has a diverse life that includes: social culture, religion and custom. The diversity of the Indonesian people is the wealth of people who were inherited from their ancestors in the struggle for independence. The culture belonging to the people should be preserved and preserved as people's habits from ancient times. The community of Atambua also has a culture that is a kind of community. It is necessary to maintain different cultures that must be preserved so that they are not easily affected or damaged by the notions of radicalism that cause the folk culture to disappear. One of the cultures of Atambua attracts the attention of the general public, which respects people's lives in different religions or beliefs. The community of Atambua has long implanted life to respect each other among religious communities. It is from this foundation or habit that it is necessary to maintain and distribute among all young citizens or pupils in Atambua, to always maintain the positive habits of the ancestors of the people of Atambua.

Citizenship teachers in Atambua junior high school see that character education is very important to do in school. The teacher is a preparation designer learning and designing learning experiences that can foster students' talent and interest in participating in classroom (Wiyani, 2013: 151). William Bennett (1991) in Wibowo (2012: 54) schools have an important role in improving the student's educational character. One of the goals of character education proposed by Kesuma et al (2011: 9) that facilitates the strengthening and development of values that can be realized in the child's behavior. Megawangi (2004: 78) Education maximally successful man is able to shape the character, it is necessary to realize a respectable nation-state. Through the establishment of good character, the students are also having a better future by preparing to reach his goal (Marsh \&Kleitman, 2005)

Development of the student's character is influenced by the culture of the school. School culture has an important role in shaping students' character. Mustakim (2011: 96) the character of the students or learners formed through tradition in this case, school culture conducive. Every society has each other's culture and have a view to developing inlife public (Woods, 2012). Herlambang (2015: 760) study of culture and national 
character can be emphasized through the internalization, the personnel and the establishment of student behavior. In addition, it is also necessary to have a relationship or positive personal interaction between teachers and learners. With children - children who have difficulties, a personal relationship between teachers and students can make all the difference through its positive influence a teacher (Lickona, 2016).

\section{CONCLUSION}

Counteracting radicalism is the duty of citizens in maintaining the security of the nation and the welfare of society. The current development of more and more radicalism which destabilize society. Judging from the development of radicalism today, many elements of society who are trying to counteract the ideologies. Schools are institutions that shape citizens become intelligent and humane by upholding nationalism. Atambua junior high school is one of the first secondary school located in the border area between countries Indonesia to Timor Leste. The efforts of the Atambua junior high school in countering radicalism In the border area through a learning process and extra school activities. In the learning process, in particular subjects Pancasila and Citizenship Education always contain materials that emphasize the values of Pancasila and nationalism in the border area with the aim to create a learner character. One of the efforts undertaken by Pancasila and Civic Education teacher at Atambua junior high school is to create drama and played by the students during the learning process. The drama composed by the teacher contains the material values of Pancasila, the attitude of nationalism, and the example of the character's students. Students who play the drama are tailored to the material and their respective roles. Students are very enthusiastic with the drama and make them very interested in the pattern or chase method used by the teacher. Students continuing information about the drama being played at the school, and then tell their friends who are not of Atambua junior high school. Their friends who feel interested in the story and then ask them to repeat the drama at the location where they play (sports). Those who watched the drama then came to the conclusion that we are careful to safeguard state security in the border area and we must always uphold the values of Pancasila and the attitude of nationalism.

\section{REFERENCES}

Alfian. Dkk. (1992). Pancasila sebagai ideologi. Jakarta. BP-7 Pusat.

Bekerman, Z., \& Zembylas, M. (2017). Engaging with religious epistemologies in the classroom: Implications for civic education. Research in Comparative and International Education, Vol. 12(1) pages:127-139.

Chen, C. (2003). East European Politics \& Societies Romania: A Historical Institutionalist. East European
Politics \& Societies Vol. 17 (2) pages: 166-201.

Gerson, G., \& Rubin, A. (2015). Cultural nationalism and liberal values: An elusive synthesis. International Political Science Review. Vol. 36 (2), pages:197-213.

Herlambang T. (2015). Pendidikan budaya dan karakter bangsa pada PKn dalam kerangka konsep pembelajaran pendidikan jasmani, olahraga dan kesehatan. Civic. Vol. 5 (1). Hlm: 760-766

Hung, C. Y. (2014). Teachers' perceptions of national identity in the: English and Taiwanese citizenship curricula: Civic or ethnic nationalism? Research in Comparative and International Education, Vol. 9 (2), pages: 197-212.

Kasuma D. dkk. (2011). Pendidikan karakter kajian teori dan praktik di sekolah. Bandung: Remaja Rosdakarya.

Kaderi,A.(2015).Pendidikan Pancasila untuk perguruan tinggi. Banjarmasin: Antasari Press

Kaelan. (2002). Pendidikan Pancasila. Yogyakarta: Paradigma.

Kaelan. (2013). Negara kebangsaan Pancasila: Kultura; hitorisitas, filosofis, yuridis, dan aktualisasinya. Yogyakarta: Paradigma.

Kawurya S. P. (2010). Pendidikan karakter di sekolah: Masihkah menjadi tanggung jawab utamaPKn?. Dinamika Pendidikan. Vol. 17 (01). Hlm: 96-104.

Koesoema D. A. (2012). Pendidikan karakter utuh dan menyeluruh. Yogyakarta: Kanisius.

Kresna, A. (2013). Pembentukan karakter generasimu dan berwawasan nilai-nilai Pancasila melalui video game bertema RPG. Areté, Vol 2 (2), hlm: 141-159.

Latif Y. (2011). Negara Paripurna: Historisitas, rasionalitas, dan aktualitas Pancasila. Jakarta: PT. Gramedia.

Leung, Y. W. (2004). Nationalistic education and indoctrination. Citizenship, Social and Economics Education, Vol. 6 (2), pages: 129-145.

Leung, Y. W., \& Yuen, T. W. W. (2012). Competition between politicized and depoliticized versions of civic education curricula: The case of Hong Kong. Citizenship, Social and Economics Education, Vol. 11 (1), pages: 45-56.

Lickona T. (2013). Pendidikan karakter panduan lengkap mendidik siswa menjadi pintar dan baik. Bandung: Nusa Media.

Lickona T. (2016). Mendidik untuk membentuk karakter. Jakarta: PT Bumi Aksara.

Ludigdo, U. (2012) Nilai-nilai Luhur Pancasila dalam Mencegah Terjadinya Kecurangan. Malang: disampaikan pada seminar nasional (Empat Pilar Kebangsaan). 
Ludigdo U, dkk. (2012). Pancasila as Accountant Ethics Imperialism Liberator. World Journal of Social Sciences. Vol. 2 (6), hlm:159 - 168.

Maftuh, B. (2008). Internalisasi nilai-nilai Pancasila dan nasionalisme melalui Pendidikan Kewarganegaraan. Educationist. Vol. 2 (2), hlm: 134-144.

Marsh, H. W., \& Kleitman, S. (2005). Consequences of Employment During High School: Character Building, Subversion of Academic Goals, or a Threshold? American Educational Research Journal, Vol. 42. (2), pages: 331-369.

Megawangi R. (2004). Pendidikan karakter solusi yang tepat untuk membangun bangsa. Jakarta: Indonesia Heritage Foundation.

Mustakim B. (2011). Pendidikan karakter membangun delapan karakter emas menuju Indonesia bermartabat. Yogyakarta: Samudra Biru.

Murdiono, M. (2014) Pendidikan Kewarganegaraan untuk membangun wawasan global warga Negara muda. Cakrawala Pendidikan, Vol. 23 (3), hlm: 349-357.

Nurdin, E. S. (2017). Civic Education policies: Their effect on university students' spirit of nationalism and patriotism. Citizenship, Social and Economics Education, Vol. 16 (1), pages: 69-82.

Rubei. M. A. (2015). Integrasi pendidikan karakter dalam pembelajaran PKn untuk mengembangkan kemandirian siswa di MTS. Mathlaul Anwar Kota Pontianak. Jurnal Pendidikan Sosial. Vol. 2 (2). Hlm: 198-211.

Salam. B. (1988). Filsafat Pancasilaisme. Bandung: Bina Aksara.

Soekarno. (2017). Filsafat Pancasila menurut bung Karno. Yogyakarta: Medio Pressindo.

Sulistyowati E. (2012). Implementasi kurikulum pendidikan karakter. Yogyakarta: Citra Aji Parama.

Suryohadiprojo S. (2014). Mengobarkan kembali api Pancasila. Jakarta. PT Kompas Media Nusantara.

Sutono, A. (2015). Meneguhkan Pancasila sebagai filsafat pendidikan nasional. Civis Vol. 5. (1). hlm: 666-678.

Tosa, M. (2015). Sport nationalism in South Korea: An ethnographic study. SAGE Open, Vol. 5(4). Pages: 1-13.

Wibowo A. (2012). Pendidikan karakter strategi membangun karakter bangsa berperadaban. Yogyakarta: Pustaka Pelajar.

Wiyani N. A. (2013). Desain pembelajaran pendidikan tata pembelajaran menuju pencapaian kompetensi. Yogyakarta: Ar-Ruzz Media.

Woods, E. T. (2012). Beyond multination federalism: Reflections on nations and nationalism in Canada. Ethnicities, Vol. 12 (3), pages: 270-292.
Weatherbee,DE.(1985). Indonesiain 1984: Pancasila, Politics, and Power. Asian Survey, Vol. 25(2. Hlm: 187197.

Yuen, T. W. W., \& Mok, F. K. T. (2014). Promoting national identification through civic education: A study of the views of civic educators in Hong Kong. Citizenship, Social and Economics Education, Vol. 13(2), pages: 8292. 